\title{
The Formation of Bridging and Bonding Social Capital to Empower Mothers from Low-income Families
}

\author{
Anif Fatma Chawa ${ }^{1}$ \\ ${ }^{1}$ Department of Sociology, Universitas Brawijaya, Indonesia \\ Correspondence: Ayu Kusumastuti, Department of Sociology, Universitas Brawijaya, Indonesia.
}

Received: December 12, 2016

Accepted: January 10, 2017

Available online: January 14, 2017

doi:10.11114/ijsss.v5i2.2065

URL: http://dx.doi.org/10.11114/ijsss.v5i2.2065

\begin{abstract}
This article presents empirical findings of research seeking to explore the formation of social capital in community development practice, that exhibits a model or mechanism by which social capital can be formed and maintained. This study also depicts how the empowerment objective can be achieved through this form of social capital. The result of this study found that the grouping mechanism established by local community development organization, namely Posdaya, has led to the formation and strengthening of social capital. The members of Posdaya have been grouped based the similarities of their interests, such as hobbies, talents, and professions. This study highlights the fact that this social capital has given rise to collective participation of the Posdaya members by sharing their knowledge, skills, and information; and finding solutions to their development problems with minimum outside intervention. These mutual and collective actions can be considered part of the self-help principle which has succeeded in empowering the members of Posdaya.
\end{abstract}

Keywords: social capital, empowerment, mothers, low-income families

\section{Introduction}

This article is a case study analysis of a local community development organization which has succeeded in empowering its members by the formation of bridging and bonding social capitals through their community development programs. There are many studies that support a similar result through demonstrating that social capital has many advantageous socioeconomic outcomes, such as democracy (Brehm \& Rahn, 1997; Putnam R. D., 1993) new technology adoption, (Isham, 1999) and poverty alleviation (Putnam R. D., 2000; Sabatini, 2009; Uyen \& Porciuncula, 2010; Holland, Kitts, da Silva, \& Wiersma, 2013). These studies demonstrate that social capital is an independent variable which contributes to the increase of intended socioeconomic outcomes through various development programs. Based on an empirical study, this article adopts a different viewpoint and demontrates how community development programs can be utilized to form social capital. The results of this study show that the building of this social capital has succeeded in achieving the community empowerment objectives of these development programs.

Social capital has been defined as a set of social relations, including trust, norms, and social networks; which are important and enable people to build communities (Putnam R. D., 1993). Putnam's concept of social capital implies that community building can be achieved by employing voluntary mutual aid and cooperation principles. Cooperation is also an important element within the process of community empowerment. Cooperation essentially describes the ways in which people organize themselves for mutual economic benefit to integrate production and consumption (Ife, 2013). The specific features of cooperation in the context of community development are that cooperation is voluntary and democratic, and the benefits are shared between members. Cooperation aims to prevent a competitive hierarchy, which is the dominant way of life in modern capitalist society and is based on individual achievement. Cooperation leads to collective progress without imposing dominance and authority. It prioritizes people sharing all aspects of living (social, political, economic, and cultural) between members.

It can be argued that mutual cooperation will provide a mechanism to build the social capital of a community. This cooperation, moreover, is required to achieve the empowerment objectives of community development programs. Kenny (2006) argues that the empowerment process involves the community's ability to have control over knowledge, information, social relationships, decision-making and resources. Thus, empowerment will succeed if communities are able to do things in their own way, using their own knowledge, information, social relations, and their own resources to improve their living conditions. 
Maintaining cooperative principles in a competitive society is not easy, but it can be reinforced by communities which have maintained their level of social capital (Putnam, 2000). This article endeavors to exhibit a model, or mechanism, by which social capital can be formed and maintained from cooperation, or working together, in the context of cooperation between mothers from low-income families. In this instance, social capital was formed by establishing a local institution, namely the Posdaya (Pos Pemberdayaan keluarga), which facilitated interaction and cooperation between its members so they could develop trust, networks, and norms; these are the important elements of social capital and can lead to the empowerment of the families involved. The Posdaya has been established as a forum through which families in rural areas can conduct and coordinate mutual or reciprocal activities including communication, advocacy, education, and sharing information to strengthen the functions of family; which are religion, culture, affection, protection, reproduction, health, education, economy, and environment (Suyono \& Haryanto, 2009). Within the Posdaya, these families have been encouraged to build mutual relationships to achieve the empowerment objectives of this program. For example, a family which has a greater capacity in terms of wealth, health, education, skills, knowledge, and information is expected to help families which have a lower level of these things. This study explores how the empowerment objective can be achieved by focusing on a case study of a Posdaya located in Desa Ngroto, Kecamatan Pujon, Kabupaten Malang, East Java Province, Indonesia.

\section{Method}

This study has implemented a single case study approach to fully capture various social capitals, including bonding, bridging, and linking capitals, which have been formed by the Posdaya members. Data was collected by utilizing depth interviews, as well as by reviewing documents and making observations. The Posdaya's documents, including legislation letters and details of organizational structure, were examined. Observation was also employed to examine the social and economic impacts of the Posdaya's community development programs on its members. Thirteen informants were purposively selected from the members of different groups of the Posdaya including the knitting, cooking, farming, herbal drink and vegetable seed growing groups.

\section{Building Bridges and Bonds of Social Capital}

This article found that mothers from low-income families have formed stronger social capital through the Posdaya of DesaNgroto. Previously, these women lacked social capital; most live in low-income neighborhoods and had conducted various productive activities to support their family income. However, they could not develop these activities for economic betterment purposes due to several impediments including: lack of capital and skill, marketing issues, lower quality, and diversification of their products. These mothers from low-income families had never worked together to find a solution to these problems.

This study found that the establishment of the Posdaya has succeeded in organizing its members to undertake their productive activities. The Posdaya has provided a model, or mechanism, for the way in which strong social capital, in the form of both bonding and building capital; as well as vertical and linking capital, can be built between the members of the Posdaya.

\subsection{Bonding Social Capital}

Putnam (1993) explains that bonding social capital is built between individuals who have the same ideology, interest, or social demography including religion, ethnicity, class, and race. Another definition states that bonding capital refers to 'relations among family members, close friends and neighbors in closed networks often lacking diversity and characterized by dense, multifunctional ties, and strong, but localized trust' (Ling \& Dale, 2013, p. 3). In relation to this study, the bonding capital has been built based on the similarity of professions, hobbies, and talents of the members of the Posdaya. Mothers from low-income families who have the same preference are gathered into one group. For instance, a mother who likes to cook will be in the same group with others who have the same hobby. There are several groups of Posdaya in Ngroto Village including groups for vegetable seed growing, farming, knitting, tailoring, setting up small shops, herbal drinks, making snacks or cooking. Figure 1 below illustrates two examples of how the members of the Posdaya have been grouped based on similarities of their interests including the same profession, hobby, or talent:

Figure 1 shows bonding capital that has been built by the Posdaya through connecting its members who have similarities in professions, hobbies, and talents. This mechanism was described by the leader of Posdaya in the following interview extracts:

The members of Posdaya have been grouped based on their hobbies and talents.....I think if people interest to knitting but they are forced to make food spices, they wouldn't make it.....That is the character of mothers in Desa Ngroto(Rusmini: the leader of Posdaya) 

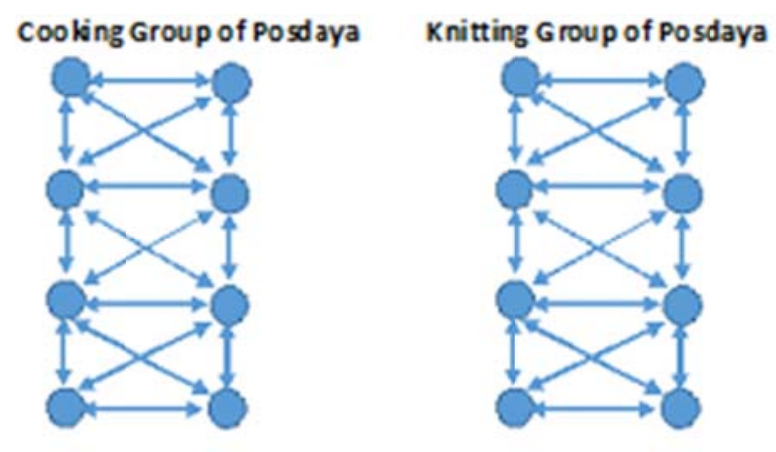

- : amember of Posdaja

$\leftrightarrow$ : social relations that have been built by Posdaya's members

Figure 1. Bonding Capital of the Posdaya

This study found that the grouping mechanism through the Posdaya has succeeded in building the bonding social capital of mothers from low-income families. This mechanism, furthermore, can then be utilized to identify various professions, hobbies, and talents of the Posdaya's members; this information can then be used to determine the different kinds of development programs, which could be conducted by the Posdaya. Figure 2 below shows structure organization of Posdaya which has been formed based on group of interest of its members:

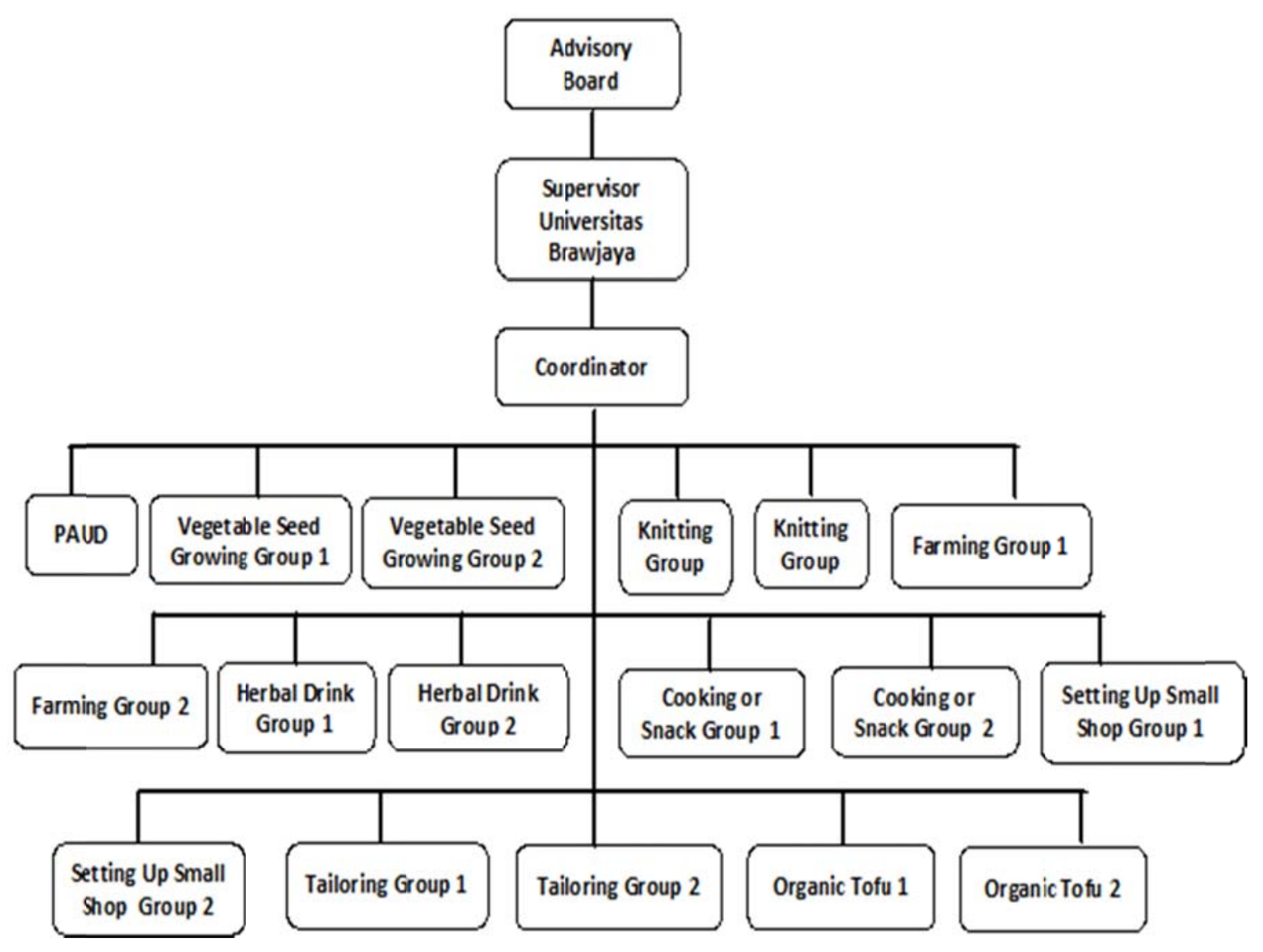

Source: Posdaya's document

Figure 2. Organization Structure of Posdaya 
Having been bonded in the same group, the members of the Posdaya are expected to have intensive social relations by sharing information and knowledge related to their professions, hobbies, and talents. The following interview excerpts illustrate the social relations, which are formed by the members of Posdaya:

If my cookies are sold out I will help my friends who still have some...for compensation I take Rp 5000 for one jar of cookies. We can't find this kind of mutual aid in the city (Ani: a member of Posdaya from cooking group)

My friend from herbal drink group has taught me how to make herbal drink from ginger. Then I tried to make it by myself.....I'm surprise that everyone like my herbal drink, now I can make and sell various herbal drink (Wati: a member of Posdaya from herbal drink group)

The results of this study reveal several instances related to social relations or mutual aid, conducted by the members of Posdaya in the same group, for example, the herbal drink members have shared their knowledge and skills to make herbal drinks for their friends in the same group. Another example is a member who has more information, knowledge, and skills in cooking will share and teach other members who have a lower capacity in this area. Other instances in relation to mutual aid conducted by members of the same group is that a member who can successfully introduce her product to the market will include the products of other members to sell in the same market. The kind of social relations which have been built by the Posdaya members have been explained by Putnam (2000), who states that bonding social capital can be employed to mobilize reciprocity and solidarity, which reinforces a homogeneous group. The members of the Posdaya, who have been grouped according to homogeneous interests, have had more intensive communication and interactions, which in turn facilitates solidarity and reinforces the bonded feeling between these members.

\subsection{Bridging Social Capital}

Putnam (in Hauberer, 2011) states that bridging capital links very different people together. In relation to bridging capital, the members of the Posdaya form this kind of capital by having social relations with other groups of the Posdaya, even though they have different professions, hobbies, and talents. Granovetter (1973) states that bridging social capital connects people, or bonded groups, and may facilitate access to resources and opportunities that exist in one network to a member of another and is characterized by weak ties. These kinds of connections have been built by the members of the Posdaya who are from different groups of professions, hobbies, and talents. The groups are illustrated in Figure 3 as follows:

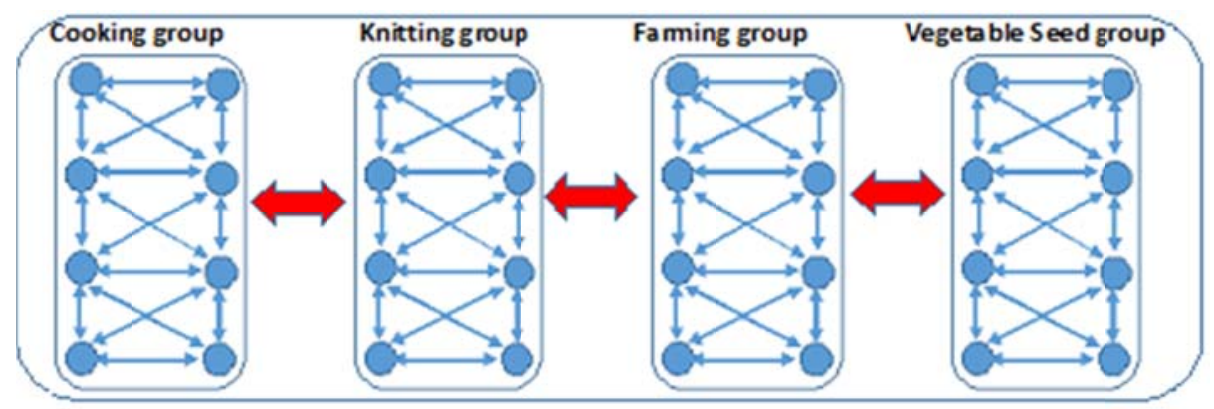

Figure 3. Bridging Capital of the Posdaya

Figure 2 illustrates social relations, which have been built by the members of the Posdaya from different groups. These relations have been included as weak ties due to the fact that each group has different characteristics in relation to professions, hobbies, and talents. The leader of the Posdaya explains that social relations between the members from different groups have been built from several activities, for instance the meetings, workshops, seminars, and training programs which have been conducted by the Posdaya. In these activities, the members of the Posdaya from different groups build communication, mutual cooperation, and share various information in relation to their productive activities as explained by an interviewee:

When we celebrate Eid Mubarak we always get many order to make various kind of cookies....I can't even have a sleep......Lucky me, there were mothers of Posdaya's members who help me to make these cookies, the leader joined with us too (Titin: a member of Posdaya from cooking group)

I was afraid if I can't sell my cookies....but when I join to Posdaya I've got many friends...I can sell my cookies to them to.... (Nani: a member of Posdaya from cooking group)

In relation to mutual cooperation, although coming from different groups, the members of Posdaya will support members from other groups who need assistance or help in conducting their businesses. For instance, the members of 
the knitting group will help the members of the cooking group when this group receives a large number of orders for special occasions such as Eid Mubarak and wedding ceremonies. The members of the knitting and other groups, additionally, have become potential customers for the snack group.

\subsection{Linking Social Capital}

As illustrated above, both bonding and bridging capital are horizontal networks which tie together individuals who have equal status and power (Hauberer, 2011). Hauberer (2011) goes on to explain that horizontal networks facilitate communication and improve the distribution of information about the trustworthiness of individuals. This study found that the establishment of the Posdaya has given rise to another kind of social capital, which is vertical and linking social capital. Vertical networks connect individuals who are located in asymmetric relations of hierarchy and dependency (Putnam R. D., 1993). This kind of network connects individuals with people in power who have influential positions either politically or financially (Woolcock, 2001). Woolcock (2001) also argues that these networks could be scaled up at the community level, civic community, namely linking social capital which attaches this community to political decision-making and financial resources and relates 'to the capacity to lever resources, ideas, and information from formal institutions beyond the community'. The establishment of linking social capital through the Posdaya can be illustrated in Figure 4 as follows:
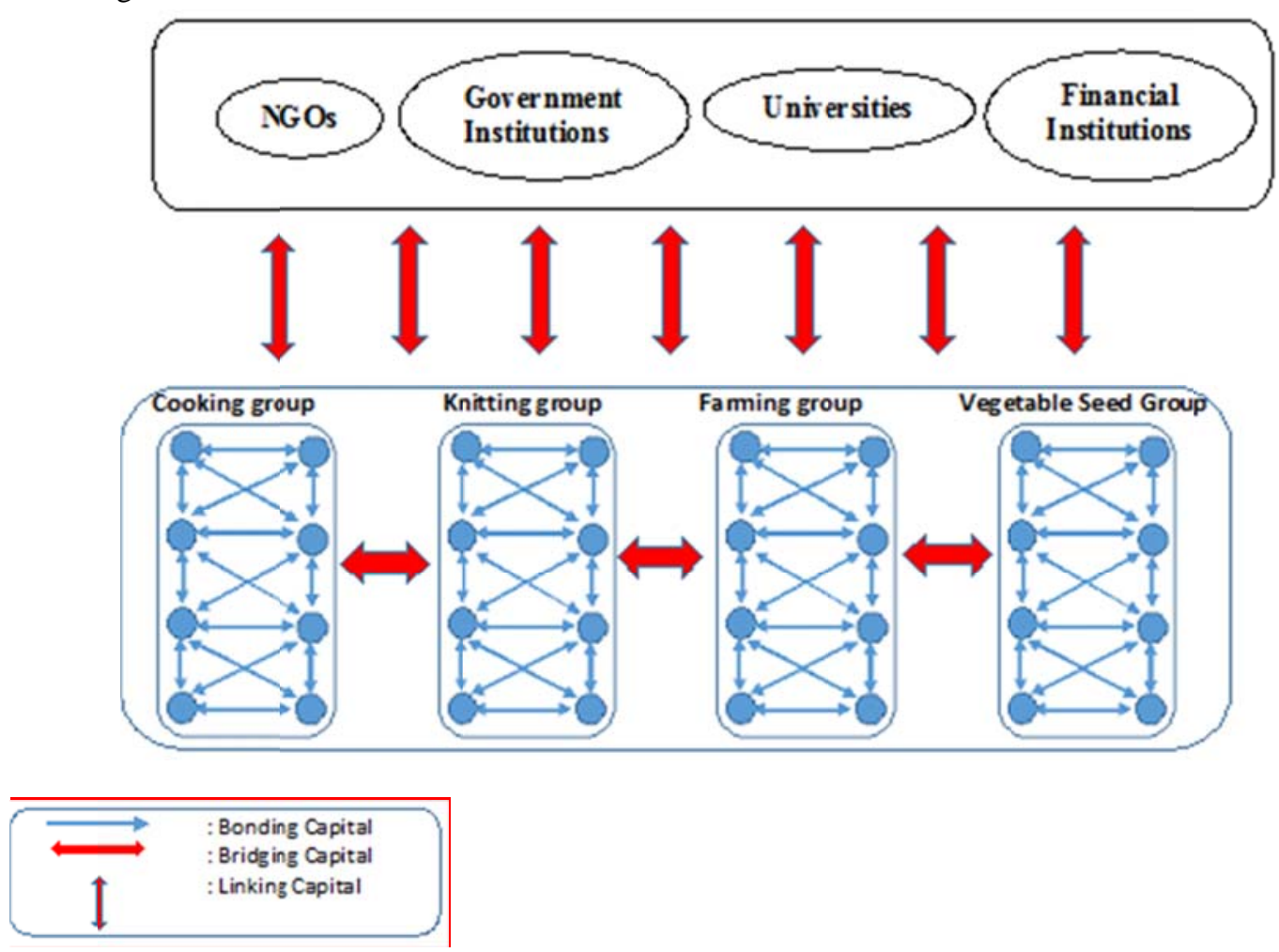

Figure 4. Linking Capital of the Posdaya

This study found that the members of the Posdaya, both at the individual and community level, have received considerable support from several institutions, including Non Government Organization (NGOs), universities, financial, and government institutions in conducting development programs as illustrated in the following interview excerpts:

I've just had a call from a NGO which want to give haircut and facial training for Posdaya's members....I already call members who prefer to join this training program (Rusmini: the leader of Posdaya)

...I'd got skill to make this cookies from training program of Program Keluarga Harapan (PKH) or Expecting Family Program of Social Ministry ....at home I practiced making it and now I can sell it (Titin: a member of Posdaya from cooking group)

Having been organized in the Posdaya, productive activities, which are conducted by the community members of Ngroto Village, could be identified more easily by the community development practitioners to give them support in regard to finances, skills, knowledge, and information to develop these activities. Furthermore, community development practitioners could conduct development programs more effectively as they deliver them right on targeted people. 


\section{Social Capital Features: Networks, Norms, and Trust}

The previous discussion illustrates how the grouping mechanism of the Posdaya has given rise to the formation of bonding, bridging, vertical, and linking social capital. As a social organization, the Posdaya has demonstrated several features which are needed to form social capital including networks, norms, and trust (Putnam, 1993). These features will facilitate coordination and cooperation for the mutual benefit of organizations, or communities, who have this social capital. Putnam's research shows that an increase in the stock of social capital, including the norms and networks of civic engagement, leads to improvements in a community's economic life and governmental performance (Putnam, 1993). The mutual benefits of a civic or social organization include the calculation of skills of its members to cooperate, a sense of shared responsibility for collective endeavors, and an increased solidarity, or moderate attitude, to other groups with diverse goals and members.

\subsection{Networks}

The social relations which have been conducted by the members of the Posdaya have formed various networks, both horizontal and vertical. In relation to horizontal networks, the members of the Posdaya have demonstrated mutual cooperation or working together with other members in the same (bonding) and different (bridging) groups in conducting their productive activities. Before the Posdaya was established, the members of the Posdaya had never worked together to undertake these activities, due to their lack of social capital. The Posdaya has provided the mechanism by which its members are able to build mutual cooperation to find solutions to their business problems; as Putnam (2000) states, cooperation, or working together, is easier in a community which has a substantial stock of social capital.The following interview excerpts illustrate mutual cooperation conducted by Posdaya's members:

I have learnt to make this cake from my friend of cooking group. Now, I can produce it..... what a surprise, this cake always sold out and I can sell many (Titin: a member of Posdaya from cooking group)

If I have a problem in conducting my business I will discuss it with my friends in Posdaya...how to solve this problem...... imagine if I think and do it by myself I will be stress (Misbah: a member of Posdaya from knitting group)

The members of the Posdaya have undertaken mutual cooperation at two levels. Firstly, this cooperation has been conducted by the members who are in the same group. For instance, the members of the cooking group have an intensive interaction and communication in conducting their hobbies. These members share their food recipes, knowledge, and skills in relation to cooking various kinds of food. Furthermore, the members of the cooking group have become 'sales representatives' for other members. They take food products from other members to be sold and receive the profit from it. Secondly, mutual cooperation has also been demonstrated by the members from different groups. As mentioned above, the members of the Posdaya also become the potential market of the cooking group to promote and sell their food products. The members of the Posdaya have utilized their networks in the Posdaya to get information to develop their businesses. Putnam (1993) states that effective cooperation will require both accurate information and reliable enforcement.

The interest group mechanism through the Posdaya has made it possible for members to establish the connections and communication required to develop their networks. Networks of civic engagement are an essential form of social capital; the more networks within a community, the more its members will be able to cooperate for mutual benefit (Putnam, 1993). By building networks, the members of the Posdaya are able to achieve several benefits including knowledge, skills, and information, as well as a potential market to develop their businesses.

\subsection{Norms}

Coleman (1998) explains that effective norms will build strong social capital. These norms should be promoted and maintained through several mechanisms, such as modeling, socialization, and sanctions (Putnam, 1993). Putnam (1993) goes on to explain that in a group or collective context, norms are able to establish social capital if they maintain individuals, so they act based on collective instead of private interest. The Posdaya has established several norms to bond its members in collective interest. Included in these norms are reciprocity, reward, and punishment.

The most important norm in building social capital is reciprocity (Putnam, 1993). The members of the Posdaya have established the norm of reciprocity, especially generalized reciprocity, in undertaking their productive activities. Generalized reciprocity refers to 'a continuing relationship of exchange that is at any given time unrequited or imbalanced, but that involves mutual expectations that a benefit granted now should be repaid in the future' (Putnam, 1993). For instance, the members of the cooking group support each other to sell and promote their food products. When one of the members has run out of their stock of snacks, the member would sell stock from other members. This member then has an expectation that friends would do the same thing if the need arose. Another instance is described in the following interview excerpts: 
We always have mutual cooperation to sell our vegetable seeds. If my seed sold out I will help my friends to promote and sell their one.....next time my friend will do the same way as I am (Wati: a member of Posdaya from vegetable seed growing group)

The same reciprocity has been demonstrated by the members of the vegetable seed growing group who sell vegetables seeds. These mothers from low-income families have grown these seeds in either their front or back yards. Their potential consumers are vegetable farmers who will buy these vegetable seeds so they can cultivate them on their own properties. Unfortunately, not all members of this group could sell all their vegetables seeds, for instance, due to the location of their homes which are too far from the road. In this situation, the members who have finished selling their seeds would provide support by offering or promoting the vegetables seeds of other members to the next customers.

In addition to the reciprocity norm, mutual cooperation has been encouraged in the Posdaya members through the establishment of a reward and punishment mechanism. This mechanism, furthermore, has been utilized to increase the participation of the Posdaya's members in its community development programs. Rewards are distributed to the members of the Posdaya who have participated intensively in the Posdaya's development programs, such as meetings and training programs conducted by NGOs, government, and academic institutions. The active members will be prioritized in terms of receiving information and assistance from donors or funding bodies to develop their businesses. On the other hand, the passive members will be disadvantaged as they will not be provided with this extra information and assistance. The head of the Posdaya explains that there are various factors which influence the participation of the Posdaya's members as illustrated inthe following interview excerpts:

It's hard to ask participation of Posdaya's members who setting up small shops. I don't know why....but I think because their lifestyle. They are already in debt trap from moneylenders because of this lifestyle. This is why I often not make a call to give them information related to development programs (Rusmini: the leader of Posdaya)

I don't know what's wrong with Minah...it's very hard to ask her to join with us....she is arrogant and too focus on herself... (Tutik: a member of Posdaya from vegetable seeds growing)

There are several factors which influence the members of Posdaya to participate in Posdaya's development programs. Included in these factors are lifestyle and the character traits of the members. There are Posdaya members who are orientated towards consumption. These members prefer to use their money for consumption rather than for productive activities. As a consequence, many become indebted to moneylenders. There are also members of the Posdaya who lack concern for their fellow members. They focus more on their own individual interests, rather than on the collective or group interests.

\subsection{Trust}

Trust is required to encourage mutual cooperation (Putnam, 1993). This means that the higher the level of trust within a community, the greater the possibility of mutual cooperation being conducted by its members. Coleman (1988) explains that the reciprocity actions, which are conducted by a community's members, will depend on two elements, and that one of those is trust. Coleman (1988, p. 102) gives the example that if A does something for B and trusts B to reciprocate in the future, this establishes an expectation in A and an obligation on the part of B. The same mechanism has been evident in the members of several groups of the Posdaya. As explained above, these members have established mutual cooperation based on the norm of reciprocity. For instance, one of the members in the vegetable seed group will help other members to sell vegetable seeds when their seed supply runs out. This means that this member has an expectation, through putting their trust in the member being assisted, and the member will be repaid by a reciprocal action in the future.

The importance of trust in building social capital is illustrated by Coleman in relation to the rotating-credit associations of Southeast Asia. 'These associations are groups of friends and neighbors who typically meet monthly. Each person contributes to a central fund that is then given to one of the members, through bidding or by lot, until, after a number of months, each of the $n$ person has made $n$ contributions and received one payout' (Coleman, 1988, p. 102). This voluntary association would not exist without a high degree of trust among the members of the groups.

This study found, however, that the problem of trust has challenged the members of several groups of the Posdaya when there is a need for mutual cooperation. One of these groups is the convenience store group whose members consist of mothers from low-income families who set up small shops or convenience stores. As illustrated in above explanation, this group has not developed when compared to other groups of the Posdaya. Most of the members of this group are indebted to moneylenders. This problem has diminished the level of trust among the members of the small shop group. This has hindered them from mutual cooperation and has had a negative effect on the norm of reciprocity, both of which are required for constituting social capital. 


\section{Social Capital and the Empowerment Objective of Community Development Programs}

Putnam (1993) states that a community, which is blessed with an inherited stock of social capital in the form of norms of reciprocity and networks of civic engagement, will conduct voluntary cooperation more easily. This inherited social capital has contributed to the increase in economic development and the stabilization of the political situation of communities in Northern Italy. Different from these communities, the mothers from low-income families, as a community of Ngroto Village, previously had a lack of social capital. This study found that the interest group mechanism, which is established through the Posdaya, has succeeded in forming and maintaining the social capital of this community. This has resulted in increasing the capacity of Posdaya members to develop their productive activities, which is in line with the empowerment objective of community development.

Community development is a development approach which allows the people or community to take control of the developments that have an impact on their lives or future. This means that the main objective of this community development approach is to achieve community empowerment. This objective can be attained if a community has the capacity to take collective responsibility to undertake their own development to achieve a better life (Kenny, 2006). To increase this capacity, a community must adopt self-help principles which require the participation of its members in the development process (Kenny, 2006; Swanepoel \& De Beer, 2006;Hustedde, 2008).

The results of this study show that the self-help principle has been adopted by the Posdaya in conducting its development programs. The establishment of the Posdaya has organized productive activities, in addition to increasing the collective participation of its members to undertake these activities. Collective participation has been constituted by the members of the Posdaya through mutual cooperation, as well as through the development of the norms of reciprocity and building trust between members, which are the elements required to form social capital. The existence of social capital has been utilized by the Posdaya's members to increase their capacity in conducting productive activities, likewise in finding solutions to the problems which hinder their implementation, with minimum outside intervention. Social capital, similar to other forms of capital, such as economic, natural, and human capital, is productive, meaning that its presence will allow a community to achieve certain ends (Putnam, 1993). There are two examples of how Posdaya members have empowered themselves by employing social capital to undertake their own productive activities.

\subsection{Knitting Group}

This group consists of mothers who have similar hobbies and interests in knitting activities. They produce various handmade knitting products, such as tablecloths, baby clothes, cushion covers, and key rings. These mothers just do knitting for a hobby. Having been organized in Posdaya, they can develop this hobby into productive activity to increase family income. Previously, they sell their products only for guests or community development practitioners souvenirs who come to Posdaya as explained by its leader as follows:

There have been many guests come to see us since we organized in Posdaya. We give or sell our knitting products as souvenirs to them (Rusmini: the leader of Posdaya)

However, this group has been challenged by marketing problems. They have not yet built networks, which would enable them to sell their handmade knitting to the market. The leader of this group, then, put forward the idea of selling their products online, using social media such as blogs; Facebook and Instagram. This will require the members to have knowledge in relation to online marketing via these social media outlets. They have been supported by community development practitioners of a university; these practitioners are conducting their development program by teaching this knowledge to them, as illustrated by an interviewee:

Students from a university who undertake their community services taught us how to run our business via social media...previously we learnt how to make a blog, now we can do it ourselves.....we just had many order from Lampung province (Yati: the leader of knitting group)

The members of the knitting group have succeeded in establishing an online marketing business through which they can sell knitting products to other provinces in Indonesia. The knitting group is also trying to expand their market to tourist destination places around their village as tourist souvenirs. As a consequence, they have to produce many knitting products with various models to sell and fulfill the orders. This study found that the members of knitting group conducted mutual cooperation to run this knitting business. The main role of the leader of this group is to share knowledge and information to other members regarding models and kinds of knitting products. Furthermore, the leader also has the responsibility to find information related to market and networks to sell knitting products. Meanwhile, the group's members collectively produce various knitting product to sell as explained by the leader in a excerpt interview as follows:

Now we're already sell our knitting product to a tourist destination place......we just send an order of key 
rings to Lampung in Eid Mubarak....we're always doing knitting together to fulfill that order (Yati: the leader of knitting group)

The above explanation depicts a process through which the members of knitting group has been empowered through grouping mechanism in Posdaya. The members have the capability to strengthen their bonding (between group's members), bridging (networking for market expanding) and linking capital (community development practitioners) to undertake knitting business to increase their family income. The social capitals have been formed through collective participation and mutual cooperation conducted by the group's members to find solutions to the problems when running their knitting business.

\subsection{Vegetable Seed Growing Group}

This group consists of mothers who cultivate vegetable seeds at the front or back yards of their properties. Like other groups of Posdaya, this group has encountered many problems including capital and marketing problems to develop their productive activities. In regard to capital problems, the members of this group have accepted financial support from a local bank. As this was organized through Posdaya, the group of vegetable seed farmers has acquired more privileges than individual bank customers, as the bank has offered them the lowest rate and waived some of the administration fees. This mechanism has allowed the members of the vegetable seed farming group to obtain credit more easily from this bank. This mechanism was described by the leader of this group in the following interview extract:

We had acquired credit from Bank Jatim (name of local bank) to increase our capital....there was no debt trap problems...all group's members had returned their credits back... (Yani: the leader of vegetable seed growing group)

This study found that the group of vegetable seed growing has strengthened its social capital through Posdaya. In regard to bonding capital, this social capital has been developed through norms of reciprocity and trust by which this group fulfilled the orders of consumers who are mostly vegetable farmers. As described in the previous explanation, this reciprocity has been conducted by the members of vegetable seed growing group to sell their seeds to customers. The members who have finished selling their seeds would help other members to sell or promote their seeds to the next customers. Moreover, having been organized in Posdaya, this group has obtained more attention from community development practitioners, which has formed its linking social capital. For instance, a local bank has allowed the group's members to have privileges in accessing credit to increase their capital. Another instance, which is the same as the knitting group, the vegetable growing seed group has been supported by students of university who conducted community services to develop online marketing via social media to sell their vegetables. Since then, the vegetable seed growing group has had customers who come from other areas and are not only vegetable farmers who live nearby.

These two examples portray the extent to which social capital can be employed to achieve the empowerment objective of community development programs. This study, however, found that not all the groups of the Posdaya could develop collective participation to increase their capacity in conducting development programs. Only the groups which have good or active leaders could form and strengthen social capital and utilize it to empower themselves. From observation, this study found that the leaders of groups dominantly have established and managed various activities of their groups, including meeting and training activities. For instance, in terms of location, most of these activities have been conducted at the group leaders' houses. Another crucial aspect is the knowledge and capacity of group members to use information technology, which could support them to develop bridging social capital; for instance online marketing via social media.

\section{Conclusion}

This study found that the stock of social capital of a community could be strengthened through a community development program, namely Posdaya. Posdaya in Desa Ngroto has developed a model, or mechanism, the way in which its members could form bonding, bridging, and linking social capital. Posdaya has grouped its members based on the similarities of their interests, such as hobbies, talents, and professions. Within this mechanism mutual cooperation, as well as the norms of reciprocity and trust building, have been developed by Posdaya members to conduct their productive activities; this has led to the formation and strengthening of social capital.

In terms of empowerment, this study shows that the presence of social capital has given rise to collective participation of the Posdaya members in conducting their productive activities. Sharing knowledge, skills, information, and finding solutions to their development problems are included in collective actions conducted by Posdaya members. These mutual and collective actions can be considered part of the self-help principle, which is required to achieve the empowerment objective of community development programs.

This is a small example of the way in which social capital can be built by a community through the implementation of 
community development program. An appropriate model or mechanism to boost collective actions of community members required to form social capital is justifiable. In order to develop a theoretical understanding of the models or mechanisms of building and maintaining social capital in relation to community development programs, this study indicates the necessity of further empirical studies in different communities.

\section{References}

Brehm, J., \& Rahn, W. (1997). Individual-Level Evidence for the Causes and Consequences of Social Capital. American Journal of Political Science, 41(3), 999-1023. https://doi.org/10.2307/2111684

Coleman, J. S. (1998). Social Capital in the Creation of Human Capital. The American Journal of Sociology, 94, 95-120. https://doi.org/10.1086/228943

Granovetter, M. S. (1973). The Strength of Weak Ties. American Journal of Sociology, 78(6), 1360-1380. https://doi.org/10.1086/225469

Hauberer, J. (2011). Social Capital Theory. New York: VS Research. https://doi.org/10.1007/978-3-531-92646-9

Holland, D., Kitts, A. W., da Silva, P. P., \& Wiersma, J. (2013). Social Capital and the Success of Harvest Cooperatives in the New England Groundfish Fishery. Marine Resource Economics, 28, 133-153. https://doi.org/10.5950/0738-1360-28.2.133

Hustedde, R. (2008). Seven Theories for seven Community Developers. New York: Routledge.

Ife, J. (2013). Community Development in Uncertain World: Vision, Analysis and Practice. Australia: Ca,bridge University Press.

Isham, J. (1999). The Effect of Social Capital on Technology Adoption: Evidence from Rural Tanzania. The Annual Meeting of the American Economic Association. New York City.

Kenny, S. (2006). Developing Communities . Melbourne: Thomson.

Ling, C., \& Dale, A. (2013). Agency and Social Capital: Characteristics and Dynamic. Community Development Journal, 4-20.

Putnam, R. (1993). The Prosperus Community: Social Capital and Public Life. The American Prospect, 13, 35-42.

Putnam, R. D. (1993). Making Democracy Work - Civic Traditions in Modern Italy. New Jersey: Princeton University press.

Putnam, R. D. (2000). Bowling Alone: The Collapse and Revival of American Community. New York: Simon Schuster. https://doi.org/10.1145/358916.361990

Sabatini, F. (2009). Social Capital as Social Networks: A New Framework for Measurement and an Empirical Ananlysis of its Determinants and Consequences. The Journal of Socio-Economics, 38, 429-442. https://doi.org/10.1016/j.socec.2008.06.001

Suyono, H., \& Haryanto, R. (2009). Buku Pedoman Pembentukan dan Pengembangan Pos Pemberdayaan Keluarga (Posdaya). Jakarta: Balai Pustaka.

Swanepoel, H., \& De Beer, F. (2006). Community Development: Breaking the Cycle of Poverty. South Africa: Juta.

Uyen, N. T., \& Porciuncula, F. L. (2010). Exploring the Extent of Social Capital in a Rural Community in Nueva. International Journal of Arts and Sciences, 3(8), 571-590.

Woolcock, M. (2001). The Place of Social Capital in Understanding Social and Economic Outcomes. ISUMA, 2(1), 11-17.

\section{Copyrights}

Copyright for this article is retained by the author(s), with first publication rights granted to the journal.

This is an open-access article distributed under the terms and conditions of the Creative Commons Attribution license which permits unrestricted use, distribution, and reproduction in any medium, provided the original work is properly cited. 